\title{
Transcript profiling of crown rootless 1 mutant stem base reveals new elements associated with crown root development in rice
}

\author{
Yoan Coudert ${ }^{1}$, Martine Bès ${ }^{2}$, Thi Van Anh Le $e^{3,4}$, Martial Pré ${ }^{3}$, Emmanuel Guiderdoni ${ }^{2}$ and Pascal Gantet ${ }^{1,3,4,5^{*}}$
}

\begin{abstract}
Background: In rice, the major part of the post-embryonic root system is made of stem-derived roots named crown roots (CR). Among the few characterized rice mutants affected in root development, crown rootless 1 mutant is unable to initiate crown root primordia. CROWN ROOTLESS1 (CRL1) is induced by auxin and encodes an AS2/LOBdomain transcription factor that acts upstream of the gene regulatory network controlling CR development.

Results: To identify genes involved in CR development, we compared global gene expression profile in stem bases of crl1 mutant and wild-type (WT) plants. Our analysis revealed that 250 and 236 genes are down- and upregulated respectively in the crl1 mutant. Auxin induces CRL1 expression and consequently it is expected that auxin also alters the expression of genes that are early regulated by CRL1. To identify genes under the early control of CRL1, we monitored the expression kinetics of a selected subset of genes, mainly chosen among those exhibiting differential expression, in crll and WT following exogenous auxin treatment. This analysis revealed that most of these genes, mainly related to hormone, water and nutrient, development and homeostasis, were likely not regulated directly by CRL1. We hypothesized that the differential expression for these genes observed in the crl1 mutant is likely a consequence of the absence of CR formation. Otherwise, three CRL1-dependent auxin-responsive genes: FSM (FLATENNED SHOOT MERISTEM)/FAS1 (FASCIATA1), GTE4 (GENERAL TRANSCRIPTION FACTOR GROUP E4) and MAP (MICROTUBULE-ASSOCIATED PROTEIN) were identified. FSM/FAS1 and GTE4 are known in rice and Arabidopsis to be involved in the maintenance of root meristem through chromatin remodelling and cell cycle regulation respectively.

Conclusion: Our data showed that the differential regulation of most genes in crll versus WT may be an indirect consequence of CRL1 inactivation resulting from the absence of CR in the crl1 mutant. Nevertheless some genes, FAS1/FSM, GTE4 and MAP, require CRL1 to be induced by auxin suggesting that they are likely directly regulated by CRL1. These genes have a function related to polarized cell growth, cell cycle regulation or chromatin remodelling. This suggests that these genes are controlled by CRL1 and involved in CR initiation in rice.
\end{abstract}

\section{Background}

Molecular mechanisms underlying initiation of new roots have been extensively studied in the plant model Arabidopsis thaliana (Arabidopsis) (for a recent review see [1]). In the embryonic primary root of Arabidopsis, new root meristems derive from pericycle founder cells. These meristems give rise to post-embryonic roots named lateral roots (LR). Several genes related to auxin,

\footnotetext{
* Correspondence: pascal.gantet@univ-montp2.fr

${ }^{1}$ Université Montpellier 2, UMR DAP, Place Eugène Bataillon, 34095

Montpellier Cedex 5, France

Full list of author information is available at the end of the article
}

involved in the mitotic competence of pericycle cells, in LR primordia initiation, patterning and LR emergence have been identified [2-7]. In cereals, the major part of the root system is made of post-embryonic stem-derived roots named crown roots (CR). Rice (Oryza sativa L.) is a relevant model to study the genetic control of CR development [8]. To date only a few rice mutants with less or no crown root have been identified. One of those is altered in CRL4 (CROWN ROOTLESS4)/OsGNOM1 that encodes an ARF-GEF (ADP-RIBOSYLATION FACTOR-GUANIDINE EXCHANGE FACTOR) $[9,10]$ and is homologous to Arabidopsis AtGNOM1 [5].
C Biomed Central

(c) 2011 Coudert et al; licensee BioMed Central Ltd. This is an Open Access article distributed under the terms of the Creative Commons Attribution License (http://creativecommons.org/licenses/by/2.0), which permits unrestricted use, distribution, and reproduction in any medium, provided the original work is properly cited. 
AtGNOM1 regulates the intracellular traffic of PIN1 (PINFORMED1) auxin efflux carrier proteins [11], and by consequence modulates polar auxin transport involved in cell division events leading to the differentiation of LR meristem [1]. The study of the crl4/Osgnom1 mutant in rice suggested that OsPIN may regulate polarised auxin transport that controls the first divisions of the ground meristem, the tissue giving birth to CR $[9,10]$. Two other mutants named adventitious rootless 1 (arl1) and crown rootless 1 (crl1) are devoid of crown root $[12,13]$. They are both affected in the ARL1/CRL1 gene (referred as CRL1 hereafter) that encodes an AS2/ LOB (ASYMMETRIC LEAVES2/LATERAL ORGAN BOUNDARIES)-domain transcription factor [14]. CRL1 is expressed in parenchyma cells adjacent to the peripheral vascular cylinder of the stem that is the area of CR initiation [12]. CRL1 expression is induced by auxin likely via direct binding of an ARF (AUXIN RESPONSE FACTOR) transcription factor (TF) to its promoter [12]. CRL1 is homologous to Arabidopsis LBD16 (LATERAL ORGAN BOUNDARIES-DOMAIN PROTEIN 16) and $L B D 29$ that are directly induced by auxin via ARF7 and ARF19 and necessary for lateral root initiation [15].

The absence of CR primordia in $\mathrm{crl1}$ mutant suggests that the CRL1 transcription factor acts upstream of the gene regulatory network that control the early steps of CR primordia differentiation. In order to identify genes involved in this process, we compared global gene expression profiles in stem bases of $\mathrm{crl} 1$ and wild-type (WT) plants, using rice expression arrays (Affymetrix). We identified 486 genes differentially expressed in the crl1 mutant. To arrange molecular events downstream of auxin and CRL1, we analysed expression kinetics of a selected subset of 47 genes in response to auxin treatment in $\mathrm{crl1}$ and WT. This allowed to identify 3 CRL1dependent auxin responsive genes. Two of them or their orthologues in A. thaliana, FSM (FLATENNED SHOOT MERISTEM)/FAS1 (FASCIATA1) and GTE4 (GENERAL TRANSCRIPTION FACTOR GROUP E4) were already reported to be involved in chromatin remodelling and to affect shoot and root development, meristem differentiation and functioning. The third one encodes a MAP (MICROTUBULE-ASSOCIATED PROTEIN) that may be involved in the control of cell division. Our results support the conclusion that these genes, and the related biological processes, are likely involved in crown root differentiation and are under the control of CRL1.

\section{Methods}

\section{Plant material and growth conditions}

Hulled seeds of wild-type and crl1 mutant rice (Oryza sativa cultivar Taichung 65) were disinfected and inoculated under sterile conditions in square Petri dishes (Corning, NY, USA) containing half strength Murashige and Skoog (MS) medium (Duchefa Biochemie B.V., The Netherlands) and 0,8\% agar type II (Sigma, MO, USA) and were incubated in a vertical position at $26^{\circ} \mathrm{C}$ and under a $12 \mathrm{~h}$ light/12 h dark photoperiod. Stem bases used for transcriptome analysis were collected from 7 day-old plantlets. For auxin treatment, seven day-old axenic seedlings were transferred in flasks containing half strength MS liquid medium, the culture medium was supplemented with $10^{-6} \mathrm{M}$ indole acetic acid (IAA) (Sigma) one day after transfer. The $c r l 1$ mutant is a kind gift of Pr. Makoto Matsuoka (Nagoya University, Japan) [12].

\section{RNA extraction and preparation}

For each biological replicate, twenty stem bases (Figure 1) were collected and immediately frozen in liquid nitrogen. RNA were extracted with Plant RNeasy (Qiagen, The Nederlands) and treated on column with Dnase (Qiagen). They were quantified with a NanoQuant at $260 \mathrm{~nm}$ wavelength and analysed for quality on a BioAnalyzer 2100 (Agilent, CA, USA). $200 \mathrm{ng}$ of total RNA were used for a single amplification. Antisense RNA strand were then biotynilated according the Affymetrix (Affymetrix, CA, USA) IVT Express protocol.

\section{Array hybridisation and analysis}

All steps were performed according manufacturer's instructions (Affymetrix, CA, USA) unless otherwise stated. Equipments were provided by Affymetrix company.

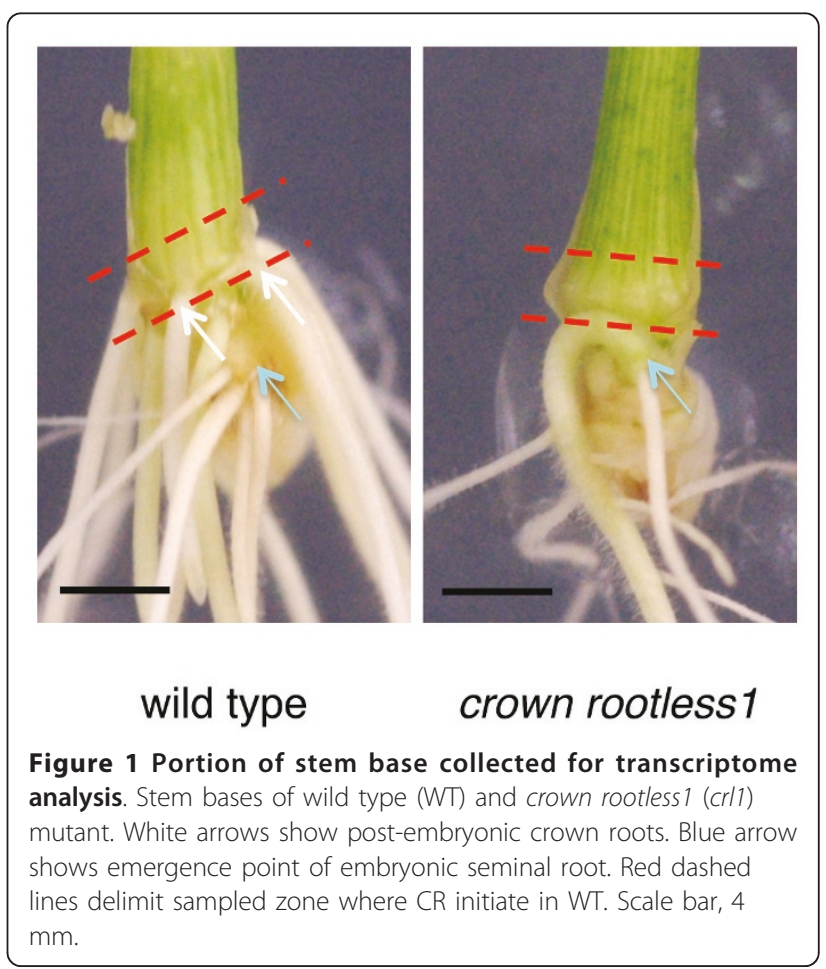


Twelve $\mu \mathrm{g}$ of biotin-labelled antisens RNAs were fragmented and hybridized to GeneChip Rice Genome Arrays (Affymetrix) for $16 \mathrm{~h}$ at $45^{\circ} \mathrm{C}$ and $60 \mathrm{rpm}$ in a Hybridisation Oven 645. Arrays were washed, labelled with phycoerythrin on the Fluidic Station 450 and read with the Scanner 3000 7G. Data acquisition was done with the GeneChip Command Console. Array pictures were analysed with MAS5 algorithm of the Expression Console software (Affymetrix). Default parameters were applied, global scaling method was used to normalise data (TGT value set at 100). A comparative analysis was carried out for each biological replicate with MAS5 algorithm in the GeneChip Operating software (Affymetrix). Probes with a "Present" Detection Call were kept for subsequent analysis, "Absent" or "Marginal" were rejected. The three biological replicates were compared. Expression of a gene was considered as differentially increased or decreased when its signal ratio was consistently superior to 2 or lower than 0,5 respectively with a $\mathrm{p}$-value $\mathrm{P} \leq 0.01$ in the three replicates. Orygenes Database http://orygenesdb.cirad.fr/ [16] was used to retrieve gene annotation in rice and in Arabidopsis corresponding to selected Affymetrix probes. Microarray data obtained in this study are available in the gene expression omnibus (GEO) database under the reference GSE30818.

\section{RT-qPCR (Reverse Transcription-quantitative Polymerase Chain Reaction)}

cDNA synthesis was performed using RQ DNase I-treated total RNA preparations (see above) and SuperScript III reverse transcriptase kit (Invitrogen). Relative transcript abundance of selected genes (See Additional file 1, Table S1) was determined using the Roche LightCycler 480 system and the LC480 SYBR Green I Master kit (Roche Applied Sciences). The range of primer efficiencies observed for the couples of primers used was comprised between 1.77 and 2. Measurements were taken for three or four biologically independent sets of samples. A technical replicate was performed for each replicate. Expression level of EXP (Os06g11070) reference gene was used to normalize gene expression level between the different timepoints [17]. We verified that both in $c r l 1$ mutant and WT, the $C t$ value of the EXP gene remained stable at different times after auxin treatment and was comprised for different independent biological and technical repetition of the experiment between 27.5 and 29. In addition, LightCycler melting curves were obtained for the reactions, revealing single peak melting curves for all amplification products. The amplification data were analysed using the second derivative maximum method, and resulting $C p$ values were converted into relative expression values using the comparative Ct method [18]. Mean values of expression levels obtained from different biological repetitions were statistically compared using a Student's t-test.

\section{Results and discussion}

Transcript profiling of crownrootless 1 stem base

Total RNAs were extracted from WT and crl1 stem bases of 7 day-old seedlings. The sampled zone was located just above the zone of emergence of CR in the WT, which correspond to the zone where CR primordia differentiate (Figure 1). RNAs were amplified, labelled and hybridised on GeneChip Rice Genome Arrays (Affymetrix). Transcript profiling of three independent biological replicates obtained from WT and crl1 were compared. Only genes exhibiting a significant induction or repression in the three replicates were selected for further analysis. We identified 250 and 236 genes downand up-regulated respectively at least twofold in the $\mathrm{crl} 1$ mutant ( $\mathrm{p}$-value, $\mathrm{P} \leq 0.01$ ). In both groups, about 200 genes were differentially regulated less than 5 -fold on average. About $10 \%$ of the genes were differentially regulated more than 5 -fold in crownrootless 1 relative to wild-type (Figure 2A). Genes were annotated automatically with function prediction in rice and Arabidopsis and categorised manually according to their putative molecular function (Figure 2B). About one third of differentially regulated genes had no predicted function and about one quarter was involved in metabolism. Most of the up-regulated genes in $\mathrm{crl1}$ (UPIC) fell into transduction, transcription factor and cell cycle/DNA categories whereas down-regulated genes in crl1 (DOIC) were rather distributed in transduction, post-translation/ proteolysis and transport categories (Figure 2B).

For all genes, and the most similar genes in Arabidopsis, we searched for published data relative to their characterised functions. The rice genome sequence has been available since 2005 [19]. Despite an important effort of the scientific community to assign to each gene a function, very few genes have been functionally characterised yet. Precise information was found for only 32 of the 486 genes identified, mostly in reference to a known function of the Arabidopsis ortholog (Figure 3). Interestingly, most of these genes had an assigned function related to signal transduction in particular auxin or to gene expression regulation (transcription factors, chromatin remodelling factors) associated with root development or meristem differentiation and functioning.

\section{Auxin-induced CRL1 expression was used to determine CRL1-dependent auxin-response genes}

In order to determine how the genes identified by transcript profiling operate in the gene regulatory network downstream of CRL1, we took advantage of the known transcriptional regulation of $C R L 1$ by auxin. Auxin (Indole Acetic Acid, IAA) activates CRL1 expression 


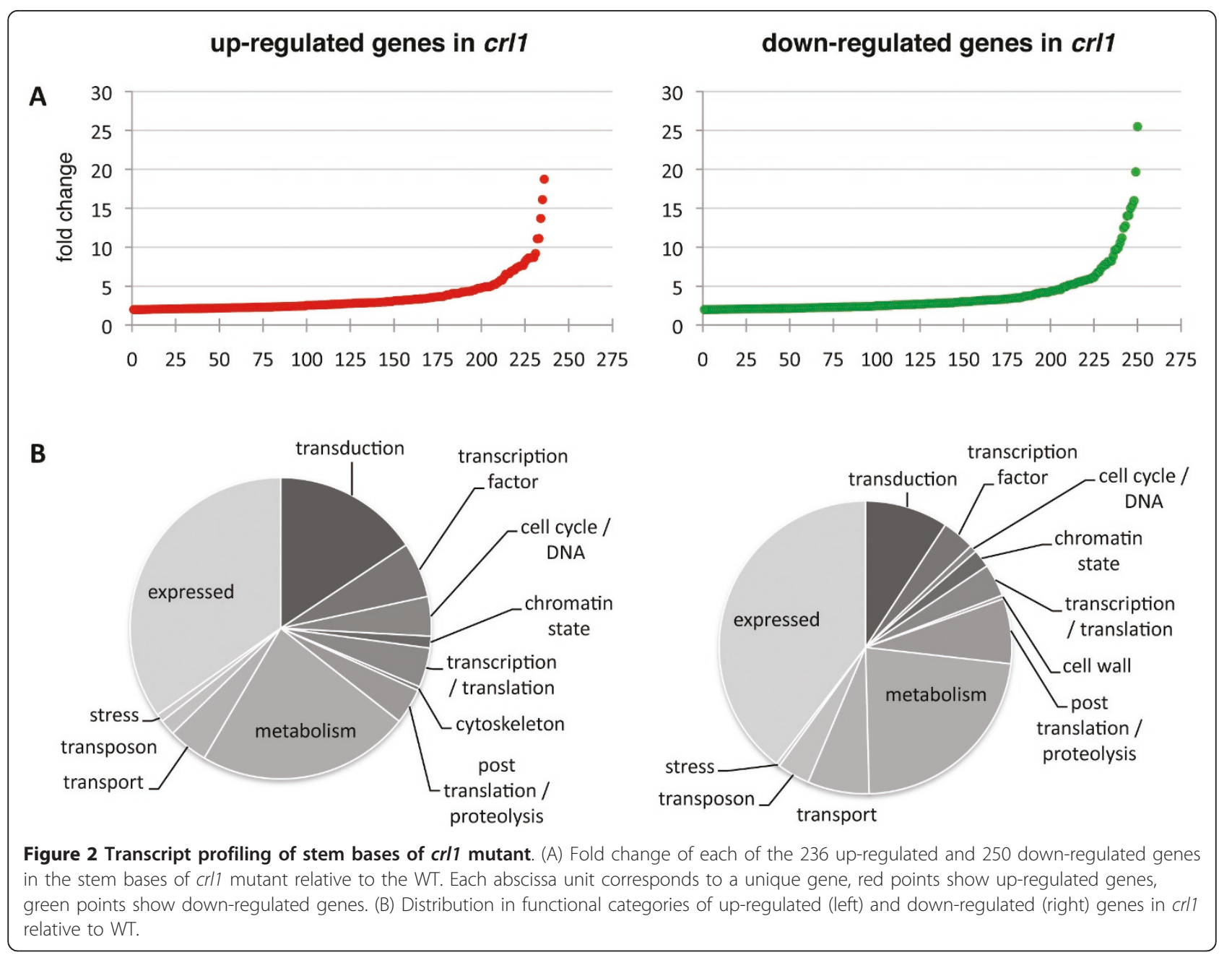

within one hour following exogenous treatment (Figure 4). As CRL1 is a transcriptional activator (our unpublished results), we anticipated that expression of CRL1 target genes would increase between 2 and 6 hours following auxin treatment in WT plants, but not in $\mathrm{crl} 1$ plants. We selected a subset of 47 genes, including most of the 32 genes previously mentioned. These genes were chosen according to a differential regulation in $\mathrm{crl} 1$ mutant relative to wild-type, their molecular function or their putative role in a developmental process based on available literature data. Expression kinetics of the selected genes in response to IAA treatment $(0,1,3$ or 6 hours) in WT and crl1 stem base was measured by RT-qPCR.

As expected, CRL1 expression was highly induced 1 hour following auxin treatment and was consistently observed among all the biological replicates with a magnitude ranging between 7 and 12-fold. CRL1 expression level decreased following one hour, as a probable result of a negative feedback loop. Expression of OsIAA4 (INDOLE ACETIC ACID4), an early auxin-responsive gene, was induced in the same time frame than CRL1 thereby confirming the efficiency of the auxin treatment $[12,20]$.

\section{Auxin homeostasis may be altered in crl1 stem base}

AUX/IAA genes encode regulatory proteins involved in auxin signal transduction that interact with ARF TF and repress their activity in absence of auxin [21]. TIR1dependent auxin perception leads to the degradation of AUX/IAA via the ubiquitin pathway and to the regulation of expression of auxin-responsive genes by ARF. This mechanism participates in the regulation of LR differentiation in Arabidopsis involving IAA14-mediated ARF7 and ARF19 repression [3,15,22]. In rice, OsARF16 is able to bind in vitro an auxin response element in the CRL1 promoter. Moreover the expression in rice of a mutated form of OsIAA31 altered in its ubiquitination site causes the inhibition of the induction of CRL1 expression by auxin [12] which results in a reduced number of CR [23]. Here we found that OsIAA14 was DOIC and that OSIAA11 and OSIAA24 were UPIC. 


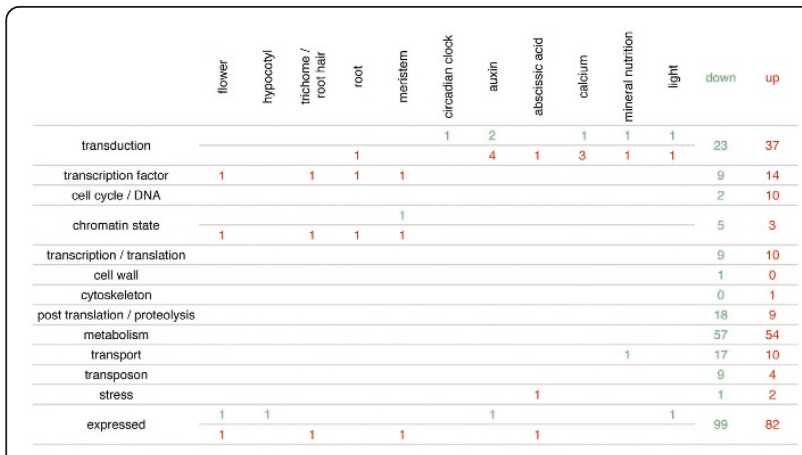

Figure 3 Genes with a physiological or developmental identified function. Functional categories are indicated in rows and physiological and developmental processes in columns. Down regulated genes are numbered in green and up regulated in red. "Down" and "Up" columns indicate total gene number for each functional category. Some genes are involved in several processes.

OsIAA11 belongs to the same expression cluster than OsIAA31 and is specifically expressed in differentiated roots and stems [20]. OsIAA14 is mostly expressed in plumule and floral organs whereas OsIAA24 is expressed in various organs including radicle or root [20]. Further RT-qPCR analysis showed that OsIAA14 and OsIAA24 were early auxin responsive genes both in WT and $c r l 1$ stem bases (Figure 5). This indicates that their regulation by auxin does not require $C R L 1$. It is likely that the absence of root meristem in the stem base of $\mathrm{crl} 1$ mutant modifies the auxin balance and results in differential regulation of auxin regulated genes independently of CRL1. This also holds true for the DOIC Os09g09370 gene which encodes OsBTBN18 (Bric-a-Brac, Tramtrack, Broad Complex BTB domain with non-phototropic hypocotyl 3 NPH3 domain) a protein presenting homology with NPH3 family proteins. In Arabidopsis

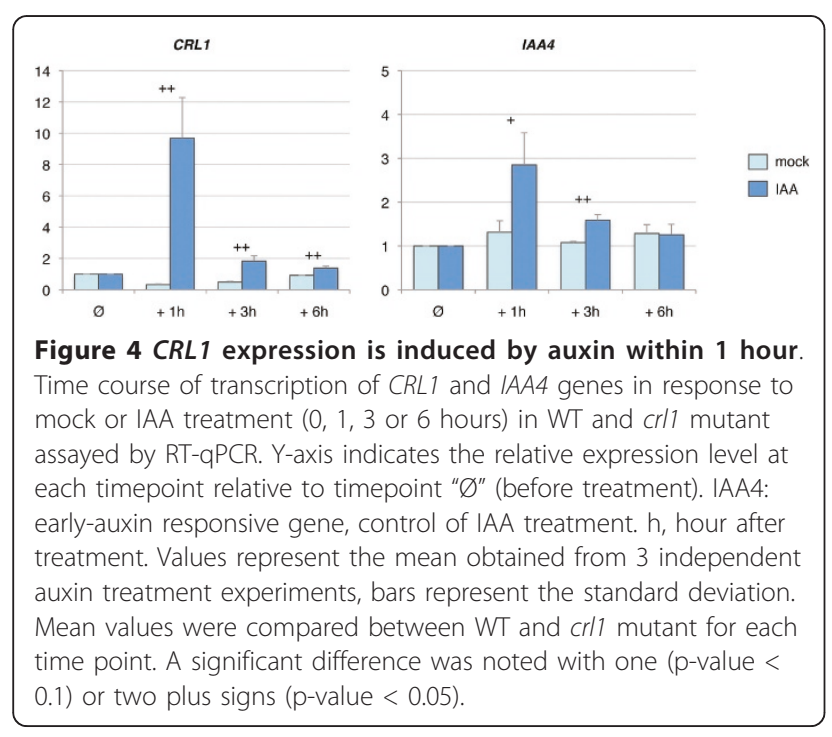

the NPY1 (NAKED PINS IN YUC MUTANTS1) gene belongs to the NPH3 gene family and regulates auxinmediated plant development [24]. NPY genes are highly expressed in root tips and contribute to root gravitropism response [25]. Further expression analysis showed that $0 s 09 g 09370$ is an early auxin responsive gene but this response to auxin did not require CRL1 (Figure 5). In this study we also characterized two late auxinresponsive genes regulated independently of CRL1: OsMIP1 (MADS-BOX INTERACTING PROTEIN1) and OSPRR95 (PSEUDO RESPONSE REGULATOR95). The DOIC OsMIP1 (Os03g55890) gene is very similar to Antirrhinum ternary complex factor MIP1 gene. MIP1 interacts with MADS-box TF involved in meristem determination during floral transition [26]. The DOIC OsPRR95 (Os09g36220) gene is orthologous to the Arabidopsis APRR5 gene belonging to the APRR1/TOC1 (TIMING OF CAB EXPRESSION 1) quintet that participates in the circadian regulation of numerous genes notably involved in flowering time and light response $[27,28]$. The latter results suggest that auxin-regulated genes involved in the control of meristem functioning are differentially regulated in the $c r l 1$ mutant, but are not under the direct control of CRL1.

\section{Expression of nutrient and water status related genes varies in $\mathrm{crl} 1$ stem base}

The absence of CR in the crl1 mutant may also modify the nutrient and water status of the plant. We further analysed the differential expression pattern of genes related to these statuses. Genes involved in mineral homeostasis and in the response to water deficit indeed appear to be differentially regulated in crl1 (Figure 3 and Table 1). The DOIC Os06g03860 gene encodes a protein orthologous to AtSPX2 (SPX: SYG1/Pho81/ XPR1: SYG1, suppressor of yeast gpal; Pho81, CDK inhibitor in yeast PHO pathway; XPR1, xenotropic and polytropic retrovirus receptor). In Arabidopsis, AtSPX2 with AtSPX1, AtSPX3 and AtSPX4 are involved in phosphate (P) homeostasis [29]. In rice OsSPX1 is a negative regulator of $\mathrm{P}$ uptake but the function of the other ones is still unknown [30]. Other genes putatively involved in ion transport such as OsO2g57240 that encodes the KOB1 ( $\mathrm{K}^{+}$CHANNEL BETA SUB-UNIT1) have been found to be differentially regulated between WT and crl1 [31].

Several UPIC genes with a function related to osmotic stress or abscissic acid were identified. Os07g05570 encodes the OsERD4 (EARLY RESPONSIVE DEHYDRATION4) protein orthologous to ZmERD4 that enhances drought and salt tolerance when constitutively expressed in Arabidopsis [32]. Os05g41070 encodes a bZIP transcription factor homologous to AtAREB3 (ABA-RESPONSIVE ELEMENT BINDING PROTEIN 3) 


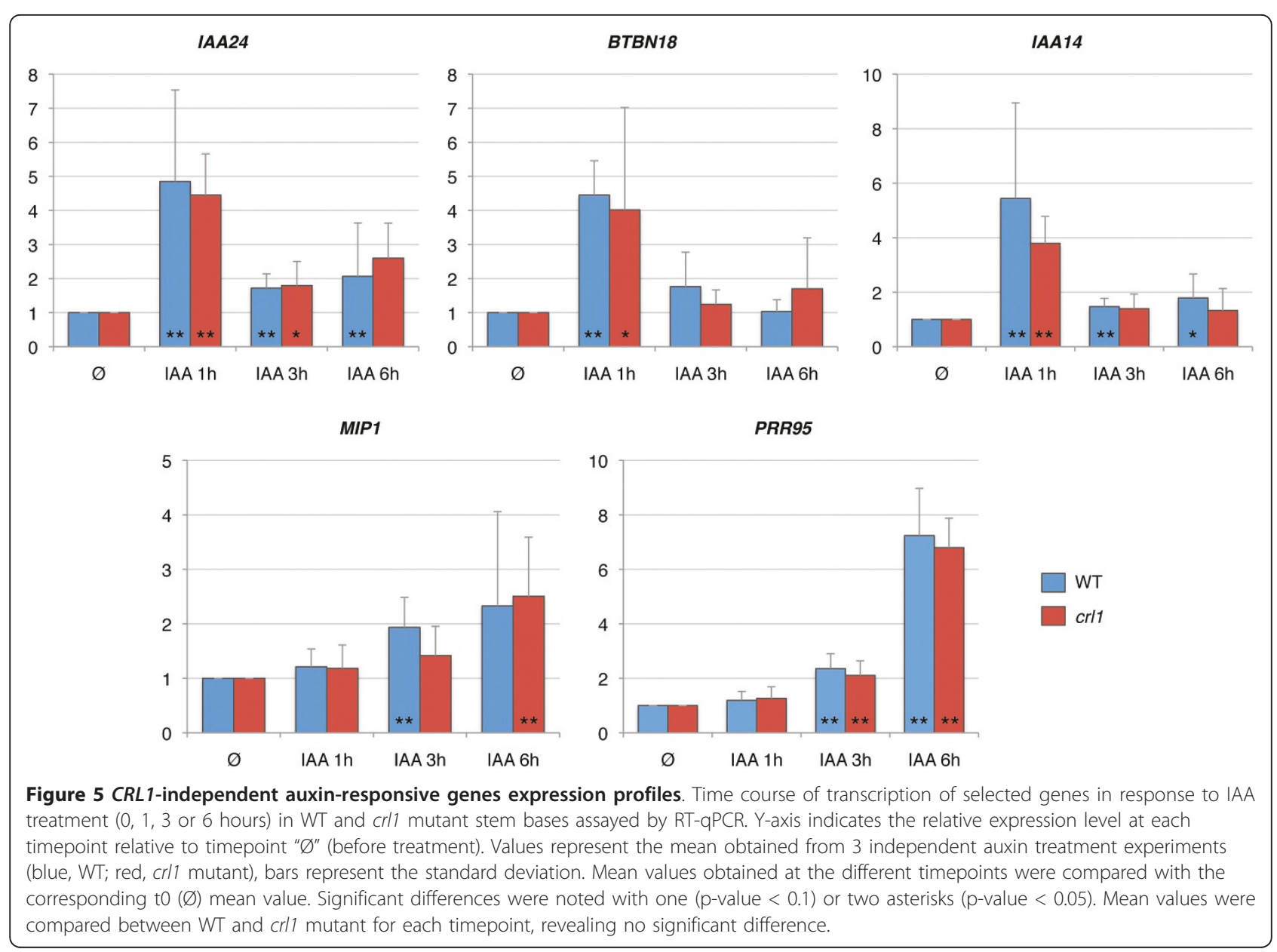

that is involved in abscissic acid signal transduction [33]. The DOIC Os05g14550 gene encodes a protein orthologous to the conserved eukaryotic TOR (TARGET OF RAPAMYCIN) kinase that promote cell growth in response to favourable conditions. In Arabidopsis AtTOR is involved in the inhibition of root growth in response to osmotic stress and excess of nitrate [34]. The absence of CR of the crl1 mutant may influence the nutrient and water status of the plant, and consequently modulate the expression of nutrient and stress related genes.

Genes related to meristem differentiation are deregulated in $\mathrm{cr} 11$ and some of them are CRL1-dependent auxin responsive genes

Several genes already identified to regulate processes involved in cell or meristem differentiation are differentially regulated in crl1. The DOIC Os08g40620 gene encodes a MAP and is a CRL1-dependent auxin responsive gene (Figure 6). This suggests that it can be a component of the gene regulatory network directly controlled by CRL1. Its function has not been determined yet either in rice or in Arabidopsis. Nevertheless the function of other MAP has been characterized in Arabidopsis. For example, AtMAP70-5 is involved in the maintenance of cellular polarity and ensures regular extension of plant organs [35]. The MAP Spiral2 mutant is defective in directional cell elongation and exhibits right-handed helical growth in longitudinally expanding organs such as the roots [36]. This suggests that the MAP encoded by Os08g40620 may be involved in polarized cellular growth during early steps of CR meristem organization regulated by CRL1.

Different genes have a function related with root hair or root meristem differentiation. The UPIC Os03g42750 gene encodes an Exocyst Complex Component SEC3 family protein orthologous to maize ROOTHAIRLESS1 protein $[37,38]$.

Several UPIC genes encode WD domain G-beta repeat domain containing proteins that can interact with TF or chromatin associated proteins to regulate gene expression and cell or meristem differentiation processes. One of them, OsTTG1 (TRANSPARENT TESTA GLABRA1) (Os02g45810), is orthologous to AtTTG1 that is involved 
Table 1 Selected genes for expression analysis by RT-qPCR in response to auxin

\begin{tabular}{|c|c|c|c|c|c|c|}
\hline & TIGR Id & FC & Annotation & $\begin{array}{c}\text { BBMH } \\
\text { Arabidopsis }\end{array}$ & Annotation & References \\
\hline \multicolumn{7}{|c|}{ UPIC (up-regulated in $c r l 1$ relative to WT) } \\
\hline & Os05g43820 & 11,11 & ras-related protein & At4g28950 & $\begin{array}{l}\text { ROP9 (RHO-RELATED PROTEIN FROM } \\
\text { PLANTS 9) }\end{array}$ & {$[54]$} \\
\hline & Os08g02490 & 8,64 & AT hook motif domain containing protein & At4g12080 & DNA-binding family protein & \\
\hline \multirow[t]{2}{*}{0} & Os02g24740 & 8,14 & $\begin{array}{l}\text { OsSAUR9 - Auxin-responsive SAUR gene family } \\
\text { member }\end{array}$ & At4g34760 & auxin-responsive family protein & {$[55,56]$} \\
\hline & Os03g51580 & 6,89 & $\begin{array}{l}\text { helix-loop-helix DNA-binding domain } \\
\text { containing protein }\end{array}$ & At2g22750 & basic helix-loop-helix (bHLH) family protein & \\
\hline \multirow[t]{2}{*}{0} & Os07g22534 & 5,78 & $\begin{array}{l}\text { WD domainG-beta repeat domain containing } \\
\text { protein }\end{array}$ & At3g49180 & $\begin{array}{l}\text { RID3 (ROOT INITIATION DEFECTIVE 3); } \\
\text { nucleotide binding }\end{array}$ & {$[40,41]$} \\
\hline & Os02g02600 & 5,06 & $\begin{array}{l}\text { serine/threonine-protein kinase Cx32chloroplast } \\
\text { precursor }\end{array}$ & At2g17220 & protein kinase & \\
\hline 0 & Os12g41900 & 4,94 & SET domain containing protein & At5g42400 & $\begin{array}{l}\text { SDG25 (SET DOMAIN PROTEIN 25)/ATXR7/ } \\
\text { MDH9 }\end{array}$ & {$[46]$} \\
\hline 0 & Os02g45810 & 4,72 & $\begin{array}{l}\text { WD domainG-beta repeat domain containing } \\
\text { protein }\end{array}$ & At5g24520 & TTG1 (TRANSPARENT TESTA GLABRA 1) & {$[57]$} \\
\hline 0 & Os03g20720 & 3,85 & GTPase-activating protein & At1g08680 & $\begin{array}{l}\text { ZIGA4 (ARF GAP-like zinc finger-containing } \\
\text { protein ZiGA4) }\end{array}$ & {$[58]$} \\
\hline 0 & Os08g40560 & 3,32 & ZOS8-11 - $\mathrm{C} 2 \mathrm{H} 2$ zinc finger protein & At2g27100 & SERRATE (SE) & [44] \\
\hline 0 & Os06g05350 & 2,96 & $\begin{array}{l}\text { whirly transcription factor domain containing } \\
\text { protein }\end{array}$ & At2g02740 & WHY3 (WHIRLY 3); DNA binding; PTAC11 & {$[59]$} \\
\hline 0 & Os01g62760 & 2,88 & protein phosphatase $2 \mathrm{C}$ & At5g59220 & protein phosphatase $2 \mathrm{CA}$ & {$[73,74]$} \\
\hline 0 & Os05g14550 & 2,86 & $\begin{array}{l}\text { Phosphatidylinositol kinase and FAT containing } \\
\text { domain protein }\end{array}$ & At1g50030 & TOR (TARGET OF RAPAMYCIN) & {$[60]$} \\
\hline 0 & Os12g06610 & 2,54 & nucleolar complex protein 2 & At3g55510 & RBL (REBELOTE) & {$[45]$} \\
\hline \multirow[t]{2}{*}{0} & Os12g01140 & 2,39 & $\begin{array}{l}\text { ACG kinases include homologs to PKAPKG and } \\
\text { PKC }\end{array}$ & At3g45780 & $\begin{array}{l}\text { PHOT1 (PHOTOTROPIN 1); protein serine/ } \\
\text { threonine kinase }\end{array}$ & [72] \\
\hline & Os01g49160 & 2,33 & MYB family transcription factor & & & \\
\hline 0 & Os05g41070 & 2,31 & bZIP transcription factor & At3g56850 & $\begin{array}{l}\text { AREB3 (ABA-RESPONSIVE ELEMENT BINDING } \\
\text { PROTEIN 3) }\end{array}$ & [33] \\
\hline $\begin{array}{l}\text { A } \\
\text { O }\end{array}$ & Os07g08460 & 2,30 & $\begin{array}{l}\text { OsIAA24 - Auxin-responsive Aux/IAA gene } \\
\text { family member }\end{array}$ & & & {$[20,61]$} \\
\hline \multirow[t]{4}{*}{0} & Os03g43890 & 2,24 & $\begin{array}{l}\text { WD domain G-beta repeat domain containing } \\
\text { protein }\end{array}$ & At5g58230 & MSI1 (MULTICOPY SUPRESSOR OF IRA1) & {$[62]$} \\
\hline & Os01g69850 & 2,13 & $\begin{array}{l}\text { OsMADS65 - MADS-box family gene with MIKC } \\
\text { type-box }\end{array}$ & & & \\
\hline & Os06g49510 & 2,06 & zinc knuckle family protein & At4g19190 & zinc knuckle (CCHC-type) family protein & [63] \\
\hline & Os07g47820 & 2,05 & acyl-CoA dehydrogenase family member 10 & At3g06810 & IBR3 (IBA-RESPONSE 3) & [64] \\
\hline 0 & Os03g43400 & 2,05 & $\begin{array}{l}\text { OsIAA11 - Auxin-responsive Aux/IAA gene } \\
\text { family member }\end{array}$ & & & {$[20,61]$} \\
\hline 0 & Os03g42750 & 2,02 & roothairless 1 & At1g47550 & AtSec3a (Exocyst complex) & \\
\hline \multicolumn{7}{|c|}{ DOIC (down-regulated in $c r l 1$ relative to WT) } \\
\hline & Os03g24930 & 25,48 & $\begin{array}{l}\text { tyrosine protein kinase domain containing } \\
\text { protein }\end{array}$ & At1g61590 & protein kinase & [65] \\
\hline & Os03g18810 & 15,00 & II-Diaminopimelate Aminotransferase & At4g33680 & $\begin{array}{l}\text { AGD2 (ABERRANT GROWTH AND DEATH 2); } \\
\text { aminotransferase }\end{array}$ & [66] \\
\hline & Os11g11790 & 8,16 & NBS-LRR type disease resistance protein & & & \\
\hline \multirow[t]{2}{*}{$\begin{array}{l}\text { A } \\
\text { O }\end{array}$} & Os03g55890 & 8,14 & ternary complex factor MIP1 & At5g66600 & unknown protein & {$[26]$} \\
\hline & Os03g07450 & 4,24 & HOX21 homeobox associated leucine zipper & At1g69780 & ATHB13 & [67] \\
\hline $\begin{array}{l}\text { A } \\
0\end{array}$ & Os09g36220 & 3,60 & $\begin{array}{l}\text { OsPRR95 - response regulator receiver domain } \\
\text { containing protein }\end{array}$ & At5g24470 & $\begin{array}{l}\text { APRR5 (ARABIDOPSIS PSEUDO-RESPONSE } \\
\text { REGULATOR 5) }\end{array}$ & [68] \\
\hline
\end{tabular}


Table 1 Selected genes for expression analysis by RT-qPCR in response to auxin (Continued)

\begin{tabular}{|c|c|c|c|c|c|c|}
\hline & Os08g41340 & 3,10 & ras-related protein & At2g31680 & $\begin{array}{l}\text { AtRABA5d (Arabidopsis Rab GTPase } \\
\text { homolog A5d) }\end{array}$ & \\
\hline & Os09g38980 & 2,81 & T-complex protein & At5g18820 & EMB3007 (embryo defective 3007) & \\
\hline \multirow[t]{2}{*}{$\begin{array}{l}\text { A } \\
0\end{array}$} & Os09g09370 & 2,64 & $\begin{array}{l}\text { BTBN18 - BTB domain with non-phototropic } \\
\text { hypocotyl } 3 \text { domain }\end{array}$ & At5g47800 & BTB - NPH3 domain & \\
\hline & Os04g55560 & 2,62 & AP2 domain containing protein & At4g36920 & PLETHORA-like transcription factor & \\
\hline $\begin{array}{c}\text { CA } \\
0\end{array}$ & Os01g67100 & 2,61 & OsFSM, expressed protein & At1g65470 & FAS1 (FASCIATA 1) & {$[48,50]$} \\
\hline CA & Os08g40620 & 2,59 & rabGAP/TBC domain-containing protein & At4g29950 & microtubule-associated protein & \\
\hline \multirow[t]{2}{*}{$\begin{array}{l}\text { A } \\
\text { O }\end{array}$} & Os03g58350 & 2,40 & $\begin{array}{l}\text { OsIAA14 - Auxin-responsive Aux/IAA gene } \\
\text { family member }\end{array}$ & & & {$[20]$} \\
\hline & Os02g08310 & 2,31 & Tubby-like protein 4 & At1g16070 & AtTLP8 (TUBBY LIKE PROTEIN 8) & [69] \\
\hline \multirow[t]{3}{*}{0} & Os06g03860 & 2,28 & uncharacterized membrane protein & At4g22990 & $\begin{array}{l}\text { SPX (SYG1/Pho81/XPR1) domain-containing } \\
\text { protein }\end{array}$ & [29] \\
\hline & Os01g07630 & 2,18 & $\begin{array}{l}\text { BRASSINOSTEROID INSENSITIVE 1-associated } \\
\text { receptor kinase }\end{array}$ & At1g60800 & NIK3 (NSP-INTERACTING KINASE 3) & \\
\hline & Os07g04700 & 2,16 & MYB family transcription factor & At3g18100 & MYB4R1 (myb domain protein 4R1) & \\
\hline 0 & Os12g37780 & 2,13 & $\begin{array}{l}\text { tetratricopeptide repeat domain containing } \\
\text { protein }\end{array}$ & At2g43040 & $\begin{array}{l}\text { NPG1 (no pollen germination 1); } \\
\text { calmodulin binding }\end{array}$ & [70] \\
\hline \multirow[t]{3}{*}{ CA } & Os02g15220 & 2,13 & bromodomain containing protein, expressed & At1g06230 & $\begin{array}{l}\text { GTE4 (GLOBAL TRANSCRIPTION FACTOR } \\
\text { GROUP E 4) }\end{array}$ & [51] \\
\hline & Os04g26850 & 2,10 & SAD2 & & & [71] \\
\hline & Os10g37640 & 2,04 & HIT zinc finger domain containing protein & At5g63830 & unknown protein & \\
\hline 0 & Os02g52990 & 2,04 & $\begin{array}{l}\text { OsSAUR12 - Auxin-responsive SAUR gene } \\
\text { family member }\end{array}$ & & & {$[20,61]$} \\
\hline 0 & Os10g23220 & 2,14 & GIL1 & At2g45260 & unknown protein & \\
\hline
\end{tabular}

in different epidermis cell differentiation pathways, including root hair differentiation in Arabidopsis [39]. Os07g22534 is homologous to AtRID3 (ROOT INITIATION DEFECTIVE3), involved in cell proliferation and in the control of adventitious root initiation in Arabidopsis $[40,41]$.

Other genes have a function related to meristem differentiation and functioning. OsO3g43890 is orthologous to AtMSI1 (MULTICOPY SUPRESSOR OF IRA1). MSI1-like WD-40 repeat proteins are components of different complexes controlling chromatin dynamics. In plants, MSI1-like proteins are involved in regulatory pathways controlling reproductive meristem transition, embryo and gametophyte development $[42,43]$. The UPIC Os08g40560 gene encodes a putative $\mathrm{C} 2 \mathrm{H} 2$ zinc finger protein and is homologous to SE (SERRATE) in Arabidopsis which is involved in miRNA gene silencing pathway that participates to coordinate meristem activity and axial patterning [44]. The DOIC Os12g06610 gene encodes a nucleolar complex protein 2 orthologous to AtRBL (REBELOTE) is involved in floral developmental homeostasis [45]. In addition the UPIC Os12g41900 gene, orthologous to AtSDG25 (SET DOMAIN GROUP25), regulates the epigenetic transcriptional activation and contributes to the regulation of FLC (FLOWERING LOCUS C), a gene involved in flowering induction in the shoot apical meristem $[46,47]$. These genes are probably not directly regulated by $C R L 1$, but their differential expression in crll suggests that the lack of CR meristem differentiation may also induce fedback regulatory pathway acting on general TF and chromatin regulatory factors known to be involved in cell and meristem differentiation.

The involvement of chromatin remodelling factor in CR initiation is supported by the fact that two genes related to this process were found to be DOIC and CRL1-dependent auxin responsive genes (Figure 6). The gene OSFSM (FLATTENED SHOOT MERISTEM) (Os01g67100) encodes a component of the CAF1 (CHROMATIN ASSEMBLY FACTOR1) complex and is orthologous to FAS1 (FASCIATA1) in Arabidopsis [48-50]. FAS1 is involved in the regulation of both shoot and root development regulation. FAS1 is strongly expressed in root tips and contributes to the maintenance of SCARECROW expression pattern which is essential to root meristem maintenance and root radial differentiation [48]. The rice $f s m$ mutant exhibits an 


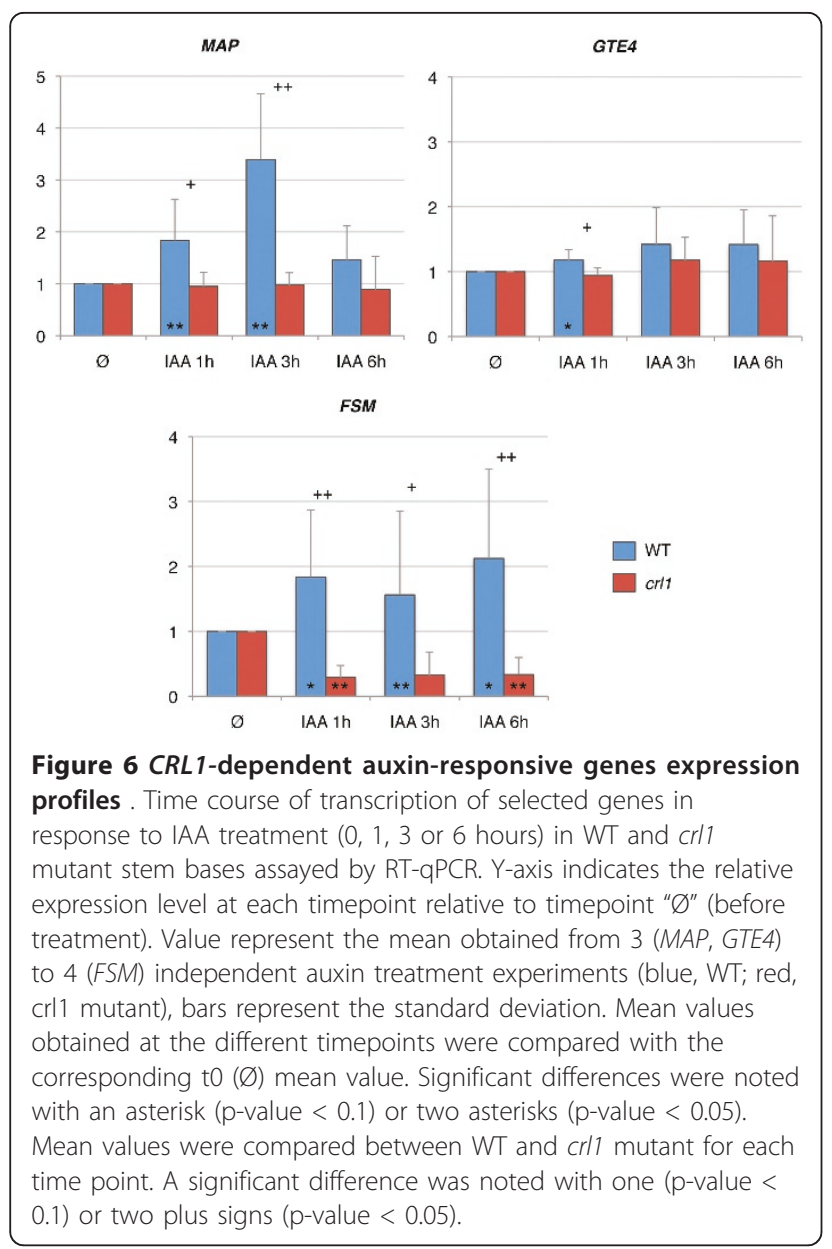

altered development including a reduced number of CR, a reduced seminal root growth and strong defects in root meristem structure. OsFSM is also expressed in root tips [50]. The other DOIC and CRL1-dependent auxin responsive gene (Os02g15220) encodes a bromodomain-containing protein homologous to the Arabidopsis GTE4. GTE4 is involved in the maintenance of the mitotic cell cycle and may be related to chromatin remodelling. In gte 4 mutants, root development is delayed and the number of lateral root is reduced. In addition, in this mutant, a partial loss of identity is observed for quiescent centre cells and the division pattern of initial cells is disrupted [51]. FSM and GTE4 play important roles in the control of root meristem differentiation and maintenance. The differential expression of FSM and OsGTE4 in response to auxin in crll mutant versus WT suggests that these genes are early CRL1 target genes and stress that chromatin structure modulation and cell cycle regulation may be essential parameters in early steps of CR meristem differentiation in rice.

\section{Conclusions}

First hypotheses toward the arrangement of the crown root differentiation gene regulatory network controlled by $C R L 1$

The differential transcriptome analysis of $\mathrm{crl} 1$ versus WT allowed the identification of a set of genes differentially regulated in $\mathrm{crl} 1$ stem base. Further RT-qPCR analysis of the response to auxin of a subset of genes in WT and crl1 was used to determine their dependence to CRL1. Some genes such as OsIAA and NPH3-like, which are involved in auxin response and auxin-mediated plant development are CRL1-independent auxin responsive genes. It is likely that the differential regulation of these genes in crl1 versus WT results from the absence of CR meristems that may modify the auxin balance in the $\mathrm{crl} 1$ mutant stem base tissues. The absence of CR in crl1 may also modify the nutrient and water status of the plant and result in the differential expression of genes involved in nutrient uptake or water stress response. Similarly the absence of CR differentiation in $\mathrm{crl} 1$ may deregulate the expression of genes involved in the control of meristem differentiation and cell division.

Three genes were found to be CRL1-dependent auxin responsive genes. They are likely directly regulated by CRL1. This concern Os08g40620 which encodes a microtubule-associated protein (MAP) that could be involved in asymmetric control of cell division during early steps of CR meristem differentiation, and the two genes FSM and GTE4 that encode chromatin

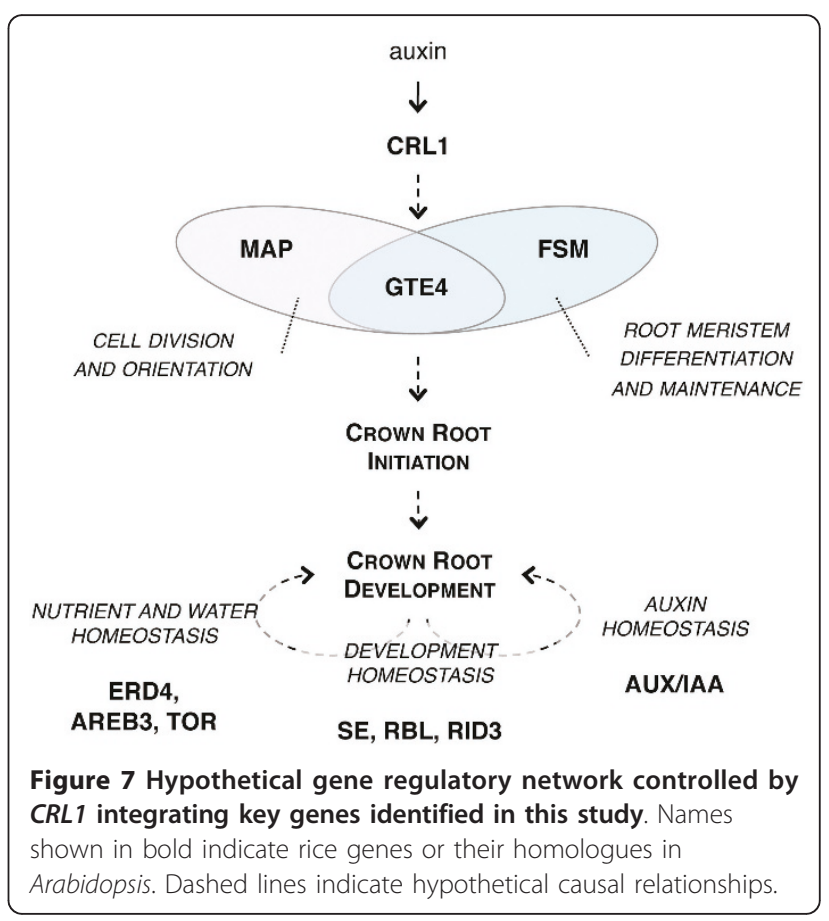


remodelling and cell cycle regulation factors known to be involved in rice or Arabidopsis on the proper cell division patterning and maintenance of the root meristem.

Figure 7 summarizes these hypotheses. Among all the genes that we have identified to be misregulated in the crl1 mutant, other CRL1-dependent auxin responsive genes remain to be identified. Their involvement in CR initiation and development will be further investigated with corresponding insertion mutants.

\section{Additional material}

Additional file 1: Genes analysed and primers used for RT-qPCR

Primers used for RT-qPCR expression analysis of the 47 genes presented in Table 1 and of EXP gene.

\section{Acknowledgements and funding}

We thank Pr. Makoto Matsuoka for providing crownrootless 1 mutant seeds. We thank Gaetan Droc for help with bioinformatics. Affymetrix microarrays were processed in the Microarray Core Facility of the Institute of Research of Biotherapy, CHRU-INSERM-UM1 Montpellier http://irb.chu-montpellier.fr/ by Veronique Pantesco. This work was financially supported by a Fellowship from the French Ministère de la Recherche et l'Enseignement Supérieur (YC) and by the University of Montpellier 2 and CIRAD.

\section{Author details}

'Université Montpellier 2, UMR DAP, Place Eugène Bataillon, 34095 Montpellier Cedex 5, France. ${ }^{2}$ CIRAD, UMR DAP, Avenue Agropolis TA A-96/ 03, 34398 Montpellier Cedex 5, France. ${ }^{3}$ Université Montpellier 2, UMR DIADE, Place Eugène Bataillon, 34095 Montpellier Cedex 5, France. ${ }^{4}$ University of Sciences and Technology of Hanoi, Department of Biotechnology and Pharmacology, Institute of Agricultural Genetics, Laboratoire Mixte International Rice Functional Genomics and Plant Biotechnology, Ha Noi, Viet Nam. ${ }^{5}$ RDD, UMR DIADE, Avenue Agropolis, 34398 Montpellier Cedex 5, France.

\section{Authors' contributions}

$Y C$ designed the research, performed the experiments and drafted the manuscript. MB, TVAL, MP participated in the RT-qPCR analysis. EG helped in drafting the manuscript. PG designed and coordinated the research and drafted the manuscript. All authors read and approved the final manuscript.

Received: 2 December 2010 Accepted: 1 August 2011

Published: 1 August 2011

\section{References}

1. Peret B, De Rybel B, Casimiro I, Benkova E, Swarup R, Laplaze L, Beeckman T, Bennett MJ: Arabidopsis lateral root development: an emerging story. Trends Plant Sci 2009, 14:399-408.

2. Dolan L, Janmaat K, Willemsen V, Linstead P, Poethig S, Roberts K, Scheres B: Cellular organisation of the Arabidopsis thaliana root. Development 1993, 119:71-84.

3. Fukaki H, Tameda S, Masuda H, Tasaka M: Lateral root formation is blocked by a gain-of-function mutation in the SOLITARY-ROOT/IAA14 gene of Arabidopsis. Plant J 2002, 29:153-168.

4. DiDonato RJ, Arbuckle E, Buker S, Sheets J, Tobar J, Totong R, Grisafi P, Fink GR, Celenza JL: Arabidopsis ALF4 encodes a nuclear-localized protein required for lateral root formation. Plant J 2004, 37:340-353.

5. Geldner N, Richter S, Vieten A, Marquardt S, Torres-Ruiz RA, Mayer U, Jurgens G: Partial loss-of-function alleles reveal a role for GNOM in auxin transport-related, post-embryonic development of Arabidopsis. Development 2004, 131:389-400.
6. Dharmasiri N, Dharmasiri S, Estelle M: The F-box protein TIR1 is an auxin receptor. Nature 2005, 435:441-445.

7. Swarup K, Benkova E, Swarup R, Casimiro I, Peret B, Yang Y, Parry G, Nielsen E, De Smet I, Vanneste $S$, et al: The auxin influx carrier LAX3 promotes lateral root emergence. Nat Cell Biol 2008, 10:946-954.

8. Coudert Y, Perin C, Courtois B, Khong NG, Gantet P: Genetic control of root development in rice, the model cereal. Trends Plant Sci 2010, 15:219-226.

9. Kitomi Y, Ogawa A, Kitano H, Inukai Y: CRL4 regulates crown root formation through auxin transport in rice. Plant Root 2008, 2:19-28.

10. Liu S, Wang J, Wang L, Wang X, Xue Y, Wu P, Shou H: Adventitious root formation in rice requires OsGNOM1 and is mediated by the OsPINs family. Cell Res 2009, 19:1110-1119.

11. Benkova E, Michniewicz M, Sauer M, Teichmann T, Seifertova D, Jurgens G, Friml J: Local, efflux-dependent auxin gradients as a common module for plant organ formation. Cell 2003, 115:591-602.

12. Inukai Y, Sakamoto T, Ueguchi-Tanaka M, Shibata Y, Gomi K, Umemura I, Hasegawa Y, Ashikari M, Kitano H, Matsuoka M: Crown rootless1, which is essential for crown root formation in rice, is a target of an AUXIN RESPONSE FACTOR in auxin signaling. Plant Cell 2005, 17:1387-1396.

13. Liu H, Wang S, Yu X, Yu J, He X, Zhang S, Shou H, Wu P: ARL1, a LOBdomain protein required for adventitious root formation in rice. Plant $J$ 2005, 43:47-56.

14. Husbands A, Bell EM, Shuai B, Smith HM, Springer PS: LATERAL ORGAN BOUNDARIES defines a new family of DNA-binding transcription factors and can interact with specific bHLH proteins. Nucleic Acids Res 2007, 35:6663-6671.

15. Okushima Y, Fukaki H, Onoda M, Theologis A, Tasaka M: ARF7 and ARF19 regulate lateral root formation via direct activation of $L B D / A S L$ genes in Arabidopsis. Plant Cell 2007, 19:118-130

16. Droc G, Ruiz M, Larmande P, Pereira A, Piffanelli P, Morel JB, Dievart A, Courtois B, Guiderdoni E, Perin C: OryGenesDB: a database for rice reverse genetics. Nucleic Acids Res 2006, 34:D736-740.

17. Caldana C, Scheible W-R, Mueller-Roeber B, Ruzicic S: A quantitative RTPCR platform for high-throughput expression profiling of 2500 rice transcription factors. Plant Methods 2007, 3:7.

18. Livak KJ, Schmittgen TD: Analysis of relative gene expression data using real-time quantitative PCR and the 2(-Delta Delta $C(T))$ Method. Methods 2001, 25:402-408.

19. The map-based sequence of the rice genome. Nature 2005, 436:793-800.

20. Song $Y$, Wang $L$, Xiong $L$ : Comprehensive expression profiling analysis of OsIAA gene family in developmental processes and in response to phytohormone and stress treatments. Planta 2009, 229:577-591.

21. Guilfoyle TJ, Hagen G: Auxin response factors. Curr Opin Plant Biol 2007, 10:453-460.

22. Okushima Y, Overvoorde PJ, Arima K, Alonso JM, Chan A, Chang C, Ecker JR, Hughes $B$, Lui A, Nguyen D, et al: Functional genomic analysis of the AUXIN RESPONSE FACTOR gene family members in Arabidopsis thaliana: unique and overlapping functions of ARF7 and ARF19. Plant Cell 2005, 17:444-463.

23. Nakamura A, Umemura I, Gomi K, Hasegawa Y, Kitano H, Sazuka T, Matsuoka M: Production and characterization of auxin-insensitive rice by overexpression of a mutagenized rice IAA protein. Plant J 2006, 46:297-306.

24. Cheng Y, Qin G, Dai X, Zhao Y: NPY1, a BTB-NPH3-like protein, plays a critical role in auxin-regulated organogenesis in Arabidopsis. Proc Natl Acad Sci USA 2007, 104:18825-18829.

25. Li Y, Dai X, Cheng Y, Zhao Y: NPY Genes Play an Essential Role in Root Gravitropic Responses in Arabidopsis. Mol Plant 2010.

26. Causier B, Cook H, Davies B: An antirrhinum ternary complex factor specifically interacts with C-function and SEPALLATA-like MADS-box factors. Plant Mol Biol 2003, 52:1051-1062.

27. Sato $E$, Nakamichi $N$, Yamashino T, Mizuno T: Aberrant expression of the Arabidopsis circadian-regulated APRR5 gene belonging to the APRR1/ TOC1 quintet results in early flowering and hypersensitiveness to light in early photomorphogenesis. Plant Cell Physiol 2002, 43:1374-1385.

28. Murakami M, Ashikari M, Miura K, Yamashino T, Mizuno T: The evolutionarily conserved OsPRR quintet: rice pseudo-response regulators implicated in circadian rhythm. Plant Cell Physiol 2003, 44:1229-1236.

29. Duan K, Yi K, Dang L, Huang H, Wu W, Wu P: Characterization of a subfamily of Arabidopsis genes with the SPX domain reveals their diverse 
functions in plant tolerance to phosphorus starvation. Plant J 2008, 54:965-975.

30. Wang C, Ying S, Huang H, Li K, Wu P, Shou H: Involvement of OsSPX1 in phosphate homeostasis in rice. Plant J 2009, 57:895-904

31. Fang Z, Kamasani U, Berkowitz GA: Molecular cloning and expression characterization of a rice K+ channel beta subunit. Plant Mol Biol 1998, 37:597-606.

32. Liu Y, Li H, Shi Y, Song Y, Wang T, Li Y: A Maize Early Responsive to Dehydration Gene ZmERD4 Provides Enhanced Drought and Salt Tolerance in Arabidopsis. Plant Molecular Biology Reporter 2009, 27:542-548.

33. Bensmihen S, Giraudat J, Parcy F: Characterization of three homologous basic leucine zipper transcription factors (bZIP) of the ABI5 family during Arabidopsis thaliana embryo maturation. J Exp Bot 2005, 56:597-603.

34. Deprost D, Yao L, Sormani R, Moreau M, Leterreux G, Nicolai M, Bedu M, Robaglia C, Meyer C: The Arabidopsis TOR kinase links plant growth, yield, stress resistance and mRNA translation. EMBO Rep 2007, 8:864-870

35. Korolev AV, Buschmann H, Doonan JH, Lloyd CW: AtMAP70-5, a divergent member of the MAP70 family of microtubule-associated proteins, is required for anisotropic cell growth in Arabidopsis. J Cell Sci 2007, 120:2241-2247.

36. Shoji T, Narita NN, Hayashi K, Asada J, Hamada T, Sonobe S, Nakajima K, Hashimoto T: Plant-specific microtubule-associated protein SPIRAL2 is required for anisotropic growth in Arabidopsis. Plant Physiol 2004, 136:3933-3944.

37. Wen TJ, Hochholdinger F, Sauer M, Bruce W, Schnable PS: The roothairless 1 gene of maize encodes a homolog of sec3, which is involved in polar exocytosis. Plant Physiol 2005, 138:1637-1643.

38. Hala M, Cole R, Synek L, Drdova E, Pecenkova T, Nordheim A, Lamkemeyer T, Madlung J, Hochholdinger F, Fowler JE, Zarsky V: An exocyst complex functions in plant cell growth in Arabidopsis and tobacco. Plant Cell 2008, 20:1330-1345.

39. Ramsay NA, Glover BJ: MYB-bHLH-WD40 protein complex and the evolution of cellular diversity. Trends Plant Sci 2005, 10:63-70.

40. Konishi M, Sugiyama M: Genetic analysis of adventitious root formation with a novel series of temperature-sensitive mutants of Arabidopsis thaliana. Development 2003, 130:5637-5647.

41. Tamaki H, Konishi M, Daimon Y, Aida M, Tasaka M, Sugiyama M: Identification of novel meristem factors involved in shoot regeneration through the analysis of temperature-sensitive mutants of Arabidopsis. Plant J 2009, 57:1027-1039.

42. Hennig L, Bouveret R, Gruissem W: MSI1-like proteins: an escort service for chromatin assembly and remodeling complexes. Trends Cell Biol 2005, 15:295-302.

43. Kohler C, Hennig L, Bouveret R, Gheyselinck J, Grossniklaus U, Gruissem W: Arabidopsis MSI1 is a component of the MEA/FIE Polycomb group complex and required for seed development. EMBO J 2003, 22:4804-4814.

44. Grigg SP, Canales C, Hay A, Tsiantis M: SERRATE coordinates shoot meristem function and leaf axial patterning in Arabidopsis. Nature 2005, 437:1022-1026.

45. Prunet N, Morel P, Thierry AM, Eshed Y, Bowman JL, Negrutiu I, Trehin C: REBELOTE, SQUINT, and ULTRAPETALA1 function redundantly in the temporal regulation of floral meristem termination in Arabidopsis thaliana. Plant Cell 2008, 20:901-919.

46. Berr A, Xu L, Gao J, Cognat V, Steinmetz A, Dong A, Shen WH: SET DOMAIN GROUP25 encodes a histone methyltransferase and is involved in FLOWERING LOCUS C activation and repression of flowering. Plant Physiol 2009, 151:1476-1485.

47. Tamada Y, Yun JY, Woo SC, Amasino RM: ARABIDOPSIS TRITHORAXRELATED7 is required for methylation of lysine 4 of histone $\mathrm{H} 3$ and for transcriptional activation of FLOWERING LOCUS C. Plant Cell 2009, 21:3257-3269.

48. Kaya H, Shibahara Kl, Taoka Kl, Iwabuchi M, Stillman B, Araki T: FASCIATA genes for chromatin assembly factor- 1 in arabidopsis maintain the cellular organization of apical meristems. Cell 2001, 104:131-142.

49. Shaw P, Dolan L: Chromatin and Arabidopsis root development. Semin Cell Dev Biol 2008, 19:580-585.

50. Abe M, Kuroshita H, Umeda M, Itoh J, Nagato Y: The rice flattened shoot meristem, encoding CAF-1 p150 subunit, is required for meristem maintenance by regulating the cell-cycle period. Dev Biol 2008, 319:384-393.
51. Airoldi CA, Rovere FD, Falasca G, Marino G, Kooiker M, Altamura MM, Citterio S, Kater MM: The Arabidopsis BET bromodomain factor GTE4 is involved in maintenance of the mitotic cell cycle during plant development. Plant Physiol 2010, 152:1320-1334.

52. Yuan $Q$, Ouyang S, Liu J, Suh B, Cheung F, Sultana R, Lee D, Quackenbush J, Buell CR: The TIGR rice genome annotation resource: annotating the rice genome and creating resources for plant biologists. Nucleic Acids Res 2003, 31:229-233.

53. Ouyang S, Zhu W, Hamilton J, Lin H, Campbell M, Childs K, ThibaudNissen F, Malek RL, Lee Y, Zheng L, et al: The TIGR Rice Genome Annotation Resource: improvements and new features. Nucleic Acids Res 2007, 35:D883-887.

54. Merchan F, de Lorenzo L, Rizzo SG, Niebel A, Manyani H, Frugier F, Sousa C, Crespi M: Identification of regulatory pathways involved in the reacquisition of root growth after salt stress in Medicago truncatula. Plant J 2007, 51:1-17.

55. Lin WH, Wang Y, Mueller-Roeber B, Brearley CA, Xu ZH, Xue HW: At5PTase13 modulates cotyledon vein development through regulating auxin homeostasis. Plant Physiol 2005, 139:1677-1691.

56. Jain M, Tyagi AK, Khurana JP: Genome-wide analysis, evolutionary expansion, and expression of early auxin-responsive SAUR gene family in rice (Oryza sativa). Genomics 2006, 88:360-371.

57. Galway ME, Masucci JD, Lloyd AM, Walbot V, Davis RW, Schiefelbein JW: The TTG gene is required to specify epidermal cell fate and cell patterning in the Arabidopsis root. Dev Biol 1994, 166:740-754

58. Sieburth LE, Muday GK, King EJ, Benton G, Kim S, Metcalf KE, Meyers L, Seamen E, Van Norman JM: SCARFACE encodes an ARF-GAP that is required for normal auxin efflux and vein patterning in Arabidopsis. Plant Cell 2006, 18:1396-1411.

59. Xiong JY, Lai CX, Qu Z, Yang XY, Qin XH, Liu GQ: Recruitment of AtWHY1 and AtWHY3 by a distal element upstream of the kinesin gene AtKP1 to mediate transcriptional repression. Plant Mol Biol 2009, 71:437-449.

60. Menand B, Desnos T, Nussaume L, Berger F, Bouchez D, Meyer C, Robaglia C: Expression and disruption of the Arabidopsis TOR (target of rapamycin) gene. Proc Natl Acad Sci USA 2002, 99:6422-6427.

61. Jain M, Kaur N, Garg R, Thakur JK, Tyagi AK, Khurana JP: Structure and expression analysis of early auxin-responsive Aux/IAA gene family in rice (Oryza sativa). Funct Integr Genomics 2006, 6:47-59.

62. Exner V, Taranto P, Schonrock N, Gruissem W, Hennig L: Chromatin assembly factor CAF-1 is required for cellular differentiation during plant development. Development 2006, 133:4163-4172.

63. Loudet O, Michael TP, Burger BT, Le Mette C, Mockler TC, Weigel D, Chory J: A zinc knuckle protein that negatively controls morning-specific growth in Arabidopsis thaliana. Proc Natl Acad Sci USA 2008, 105:17193-17198.

64. Adham AR, Zolman BK, Millius A, Bartel B: Mutations in Arabidopsis acylCoA oxidase genes reveal distinct and overlapping roles in betaoxidation. Plant J 2005, 41:859-874.

65. Cao D, Cheng H, Wu W, Soo HM, Peng J: Gibberellin mobilizes distinct DELLA-dependent transcriptomes to regulate seed germination and floral development in Arabidopsis. Plant Physiol 2006, 142:509-525.

66. Watanabe N, Cherney MM, van Belkum MJ, Marcus SL, Flegel MD, Clay MD, Deyholos MK, Vederas JC, James MN: Crystal structure of LLdiaminopimelate aminotransferase from Arabidopsis thaliana: a recently discovered enzyme in the biosynthesis of L-lysine by plants and Chlamydia. J Mol Biol 2007, 371:685-702.

67. Hanson J, Johannesson H, Engstrom P: Sugar-dependent alterations in cotyledon and leaf development in transgenic plants expressing the HDZhdip gene ATHB13. Plant Mol Biol 2001, 45:247-262.

68. Nakamichi N, Kiba T, Henriques R, Mizuno T, Chua NH, Sakakibara H: PSEUDO-RESPONSE REGULATORS 9,7 , and 5 are transcriptional repressors in the Arabidopsis circadian clock. Plant Cell 2010, 22:594-605.

69. Lai CP, Lee $\mathrm{CL}$, Chen PH, Wu SH, Yang CC, Shaw JF: Molecular analyses of the Arabidopsis TUBBY-like protein gene family. Plant Physiol 2004, 134:1586-1597.

70. Golovkin M, Reddy AS: A calmodulin-binding protein from Arabidopsis has an essential role in pollen germination. Proc Natl Acad Sci USA 2003, 100:10558-10563.

71. Verslues PE, Guo Y, Dong CH, Ma W, Zhu JK: Mutation of SAD2, an importin beta-domain protein in Arabidopsis, alters abscisic acid sensitivity. Plant J 2006, 47:776-787. 
72. Reymond P, Short TW, Briggs WR, Poff KL: Light-induced phosphorylation of a membrane protein plays an early role in signal transduction for phototropism in Arabidopsis thaliana. Proc Natl Acad Sci USA 1992, 89:4718-4721.

73. Leung J, Bouvier-Durand M, Morris PC, Guerrier D, Chefdor F, Giraudat J: Arabidopsis $\mathrm{ABA}$ response gene $\mathrm{AB}$ I1: features of a calcium-modulated protein phosphatase. Science 1994, 264:1448-1452.

74. Meyer $\mathrm{K}$, Leube MP, Grill E: A protein phosphatase $2 \mathrm{C}$ involved in $\mathrm{ABA}$ signal transduction in Arabidopsis thaliana. Science 1994, 264:1452-1455.

doi:10.1186/1471-2164-12-387

Cite this article as: Coudert et al: Transcript profiling of crown rootless 1 mutant stem base reveals new elements associated with crown root development in rice. BMC Genomics 2011 12:387.

Submit your next manuscript to BioMed Central and take full advantage of:

- Convenient online submission

- Thorough peer review

- No space constraints or color figure charges

- Immediate publication on acceptance

- Inclusion in PubMed, CAS, Scopus and Google Scholar

- Research which is freely available for redistribution

Submit your manuscript at www.biomedcentral.com/submit 